\title{
IMPLEMENTASI INOVASI MODEL-MODEL PERMAINAN MELALUI AKTIVITAS FISIK DAN GERAK PADA ANAK USIA 7-12 TAHUN DI DESA TOHUDAN
}

\author{
Karlina Dwijayanti ${ }^{1}$, Rima Ferbrianti ${ }^{2}$, Mokhammad Firdaus ${ }^{3}$ \\ ${ }_{1,2}$ Universitas Tunas Pembangunan,Indoneisa \\ ${ }^{3}$ Universitas Nusantara PGRI Kediri, Indonesia \\ ${ }^{1}$ karlinadwijayanti87@gmail.com
}

\begin{abstract}
Tohudan Village, Colomadu District, Karanganyar Regency has a larger number of children. There is a tendency for children to not know each other and their interactions between neighbors has started to decrease. The existence of an internet mobile tablet, the children tend to be inactive or have very less physical activity behavior, the children are more enthusiastic to sit down to play games on their respective cellphones or compete with each other even though they gather in the same place but only see their cellphones. respectively. This phenomenon inspires the author to do community service by making game models that are packaged through innovations to increase children's enthusiasm for physical activity and movement. This service activity aims to provide physical activity and movement activities through innovative game models for children aged 7-12 years in Tohudan village, as well as providing direction to parents so that children can interact with other children so that children's physical activity can increase. The target audience in this activity is a group of children in Tohudan village, Colomadu. The method used in this activity is parental counseling, practice of game models, monitoring and mentoring. The material provided includes: The importance of efforts to overcome the tendency to use gadgets / cellphones to children through parenting to parents, the application of innovative game models to children so that they can contribute to the formation of children's character through physical activity and movement to the environment.
\end{abstract}

Keywords: Keywords consist of two to five relevant words/phrases seperated with semicolon

\begin{abstract}
Abstrak
Desa Tohudan, Kecamatan Colomadu, Kabupaten Karanganyar memliki jumlah usia anak-anak lebih besar. Kecenderungannya usia anak tidak saling kenal dan interaksinya antar tetangga sudah mulai berkurang. Adanya tablet ponsel internet anak-anak cenderung tidak aktif bergerak atau perilaku aktivitas fisik sangat kurang sekali, anak-anak lebih antusisas duduk untuk maen games diponsel masing-masing atau saling berkompetisi walaupun mereka kumpul dalam satu tempat yang sama tetapi yang dilihat hanya ponsel masing-masing. Fenomena ini menggugah penulis melakukan pengabdian masyarakat dengan membuat model-model permainan yang dikemas melalui inovasi untuk meningkatkan antusiame anak melakukan aktivitas fisik dan gerak. Kegiatan pengabdian ini bertujuan memberikan kegiatan aktivitas fisik dan gerak melalui inovasi model -model permainan kepada anak-anak usia 7-12 tahun desa tohudan, serta memberikan pengarahan kepada orang tua agar anak bisa berinteraksi dengan anak lain sehingga aktivitas fisik anak dapat meningkat. Khalayak sasaran dalam kegiatan ini adalah kelompok anak-anak di desa tohudan, colomadu. Metode yang digunakan dalam kegiatan ini adalah dengan penyuluhan orang tua, praktek model-model permainan, monitoring dan pendampingan. Materi yang diberikan meliputi : Pentingnya upaya mengatasi kecenderungan pemakaian gadget/hp kepada anak melalui parenting kepada orangtua, pengaplikasian inovasi model-model permainan kepada anak sehingga dapat memberikan kontribusi dalam pembentukan karakter anak melalui aktivitas fisik dan gerak terhadap lingkungan.
\end{abstract}

Kata Kunci: inovasi, permainan anak, aktivitas fisik, usia 7-12 tahun 


\section{Pendahuluan}

Aktivitas fisik merupakan setiap pergerakan tubuh akibat kontraksi otot rangka yang membutuhkan kalori lebih besar daripada pengeluaran energi saat istirahat. Aktivitas fisik yang tidak dilakukan secara terstruktur dan terencana disebut aktivitas fisik sehari hari, klasifikasi aktivitas fisik berdasarkan kebutuhan energi terbagi atas aktivitas fisik ringan, sedang dan berat. Aktivitas fisik ringan adalah segala sesuatu yang menggerakkan tubuh, sama dengan aktivitas sehari-hari meliputi berjalan kaki dan pekerjaan rumah tangga. Aktivitas fisik sedang merupakan kegiatan yang membutuhkan gerakan otot yang terus menerus dengan intensitas ringan, seperti bersepeda, berlari kecil dan berjalan cepat. Aktivitas fisik berat merupakan pergerakan tubuh yang memerlukan banyak gerakan otot dan pembakaran kalori yang besar meliputi kegiatan seperti berenang, naik gunung, dan angkat beban (Linder, 1992).

Aktivitas anak usia dasar cenderung memiliki aktivitas fisik dan gerak lebih tinggi dimana aktivitas fisik dan gerak tersebut sangat dibutuhkan dalam meningkatkan perkembangan motoric dan kognitif mereka. Dengan adanya tablet, gadget/ponsel, internet anak-anak cenderung tidak aktif bergerak atau perilaku aktivitas fisik sangat kurang sekali, anak-anak lebih antusisas duduk untuk maen games diponsel masingmasing atau saling berkompetisi walaupun mereka kumpul dalam satu tempat yang sama tetapi yang dilihat hanya ponsel masing-masing. Fenomena ini sudah banyak terjadi apalagi dalam masa liburan sekolah, dari kurangnya aktivitas fisik ini maka saya membuat model-model permainan yang dikemas melalui inovasi untuk meningkatkan antusian anak melakukan aktivitas fisik dan gerak sehingga anak menjadi lebih aktif bergerak tanpa ponsel atau tablet mereka dan anak menjadi lebih kreatif dalam menunjang kegiatan lain. Aktivitas fisik ini dapat dilakukan dalam ruang terbuka maupun dilapangan dengan bentuk permainan yang inovatif, efektif serta menyenangkan sehingga dapat meningkatkan kemampuan fisik, kepercayaan diri, keberanian dan kreatifitas. Berbagai model permainan ini mempunyai tujuan dari masing-masing sehingga anak dapat meningkatkan kemampuan gerak dan fisiknya. Metode yang digunakan yaitu simulasi penerapan model permainan melalui pengalaman yang penuh kegembiraan. Keberadaan metode sebagai alat menyampaikan materi penting dalam proses pembelajaran karena dengan metode yang tepat materi pembelajaran yang sudah siap diajarkan dapat diterima dengan mudah oleh siswa melalui kegiatan belajar yang aktif. Mulyasa (2010:25) mengatakan bahwa guru harus pandai memilih metode yang tepat digunakan dalam proses belajar siswa. Kenyataannya di lapangan tidak semua guru dapat memilih metode pembelajaran yang tepat dalam pembelajaran. Salah satu ruang lingkup pendidikan jasmani adalah pembentukan gerak, yang meliputi keinginan untuk bergerak, menghayati ruang waktu dan bentuk termasuk perasaan irama, mengenal kemungkinan gerak diri sendiri, memiliki keyakinan gerak dan perasaan sikap (kinestetik) dan memperkaya kemampuan gerak (Saputra, 2000). Kemampuan gerak dasar ada tiga jenis yaitu lokomotor, nonlokomotor dan manipulatif. Aktivitas fisik merupakan setiap pergerakan tubuh akibat kontraksi otot rangka yang membutuhkan kalori lebih besar dari pada pengeluaran energy saat istirahat. Aktivitas fisik yang tidak dilakukan secara terstruktur dan terencana disebut aktivitas fisik sehari- hari, klasifikasi aktivitas fisik berdasarkan kebutuhan energy terbagi atas aktivitas fisik ringan, sedang dan berat. Aktivitas fisik ringan adalah segala sesuatu yang 
menggerakkan tubuh, sama dengan aktivitas sehari-hari meliputi berjalan kaki dan pekerjaan rumah tangga. Aktivitas fisik sedang merupakan kegiatan yang membutuhkan gerak anotot yang terus menerus dengan intensitas ringan, seperti bersepeda, berlari kecil dan berjalan cepat. Aktivitas fisik berat merupakan pergerakan tubuh yang memerlukan banyak gerakan otot dan pembakaran kalori yang besar meliputi kegiatan seperti berenang, naik gunung, dan angkat beban (Linder,1992).

Aktifitas anak usia dasar cenderung memiliki aktivitas fisik dan gerak lebih tinggi dimana aktivitas fisik dan gerak tersebut sangat dibutuhkan dalam meningkatkan perkembangan motorik dan kognitif mereka. Dengan adanya tablet ponsel internet anakanak cenderung tidak aktif bergerak atau perilaku aktivitas fisik sangat kurang sekali, anak-anak lebih antusisas duduk untuk maen games diponsel masing-masing atau saling berkompetisi walaupun mereka kumpul dalam satu tempat yang sama tetapi yang dilihat hanya ponsel masing-masing. Fenomena ini sudah banyak terjadi apalagi dalam masa liburan sekolah, dari kurangnya aktivitas fisik ini maka saya membuat model-model permainan yang dikemas melalui inovasi untuk meningkatkan antusian anak melakukan aktivitas fisik dan gerak sehingga anak menjadi lebih aktif bergerak tanpa ponsel atau tablet mereka dan anak menjadi lebih kreatif dalam menunjang kegiatan lain. Aktifitas fisik ini dapat dilakukan dalam ruang terbuka maupun dilapangan dengan bentuk permainan yang inovatif, efektif serta menyenangkan sehingga dapat meningkatkan kemampuan fisik, kepercayaan diri, keberanian dan kreatifitas. Berbagai model permainan ini mempunyai tujuan dari masing-masing sehingga anak dapat meningkatkan kemampuan gerak dan fisiknya. Metode yang digunakan yaitu simulasi penerapan model permainan melalui pengalaman yang penuh kegembiraan. Keberadaan metode sebagai alat menyampaikan materi penting dalam proses pembelajaran karena dengan metode yang tepat materi pembelajaran yang sudah siap diajarkan dapat diterima dengan mudah oleh siswa melalui kegiatan belajar yang aktif. Mulyasa (2010:25) mengatakan bahwa guru harus pandai memilih metode yang tepat digunakan dalam proses belajar siswa. Kenyataannya di lapangan tidak semua guru dapat memilih metode pembelajaran yang tepat dalam pembelajaran. Salah satu ruang lingkup pendidikan jasmani adalah pembentukan gerak, yang meliputi keinginan untuk bergerak, menghayati ruang waktu dan bentuk termasuk perasaan irama, mengenal kemungkinan gerak diri sendiri, memiliki keyakinan gerak dan perasaan sikap (kinestetik) dan memperkaya kemampuan gerak (Saputra,2000). Kemampuan gerak dasar ada tiga jenis yaitu lokomotor, non lokomotor dan manipulative. Dari hasil wawancara serta pengamatan kepada orangtua anak, kelompok anak-anak usia 7-12 tahun Desa Tohudan berkeinginan untuk dapat membuat aktif dan dapat bersosialisasi dengan teman yang lain dan tidak cenderung cuma dirumah bermain games atau menonton TV saja. Setelah mengkaji potensi yang ada di wilayah tersebut disepakati untuk mengaplikasikan kegiatan ini yaitu implementasi inovasi model permainan melalui aktivitas fisik dan gerak anak-anak usia 7-12 tahun desa Tohudan. Karena banyaknya banyak anak sekarang sosialisasinya dan rasa kebersamaanya semakin berkurang sehingga tim PKM memutuskan untuk menjadikan inovasi model permainan ini untuk meningkatakan kemampuan fisik anak dan dapat memberikan kontribusi dalam pembentukan karakter anak. Tim PKM berusaha memberikan gambaran mengenai inovasi model-model permainan yang akan dipraktekan langsung kepada anak-anak dan juga manfaat melakukan kativitas fisik dan derak tersebut. Tim PKM juga ingin mengatasi 
kecenderungan pemakaian gadget/hp kepada anak melalui parenting kepada orangtua, pengaplikasian inovasi model-model permainan kepada anak sehingga dapat memberikan kontribusi dalam pembentukan karakter anak melalui aktivitas fisik dan gerak terhadap lingkungan.

Dari hasil diskusi dengan bapak lurah Desa Tohudan, Colomadu maka dilakukan pertemuan dengan mengundang kelompok Orangtua anak Desa Tohudan. Upaya ini ternyata mendapat sambutan positif dari orangtua maupun anak-anak desa Tohudan usia 7-12 tahun. Kelompok orangtua tertarik untuk mengikuti kegiatan parenting yang bertema mengatasi kecenderungan pemakaian gadget/hp kepada anak. Berdasar hasil observasi inilah Tim mengusulkan proposal PKM untuk membantu membuat alat inovasi model permainan. Setelah berhasil melakukan pelatihan parenting kepada orangtua anak dan diterapkan inovasi model permainan tersebut.

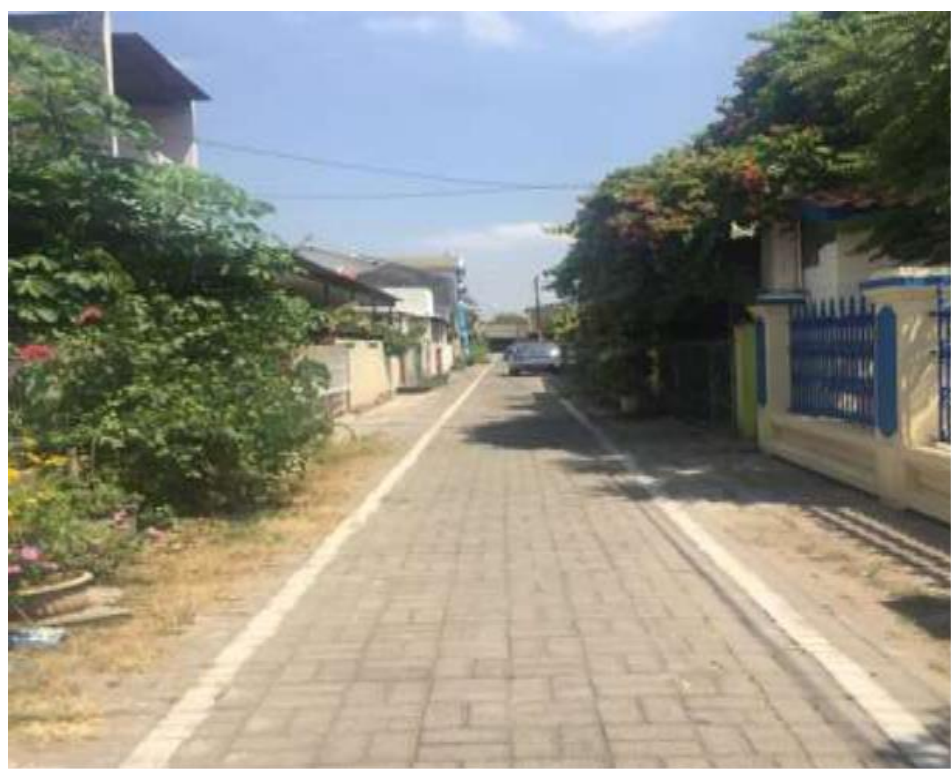

Gambar 1. Kondisi sudah banyak perumahan

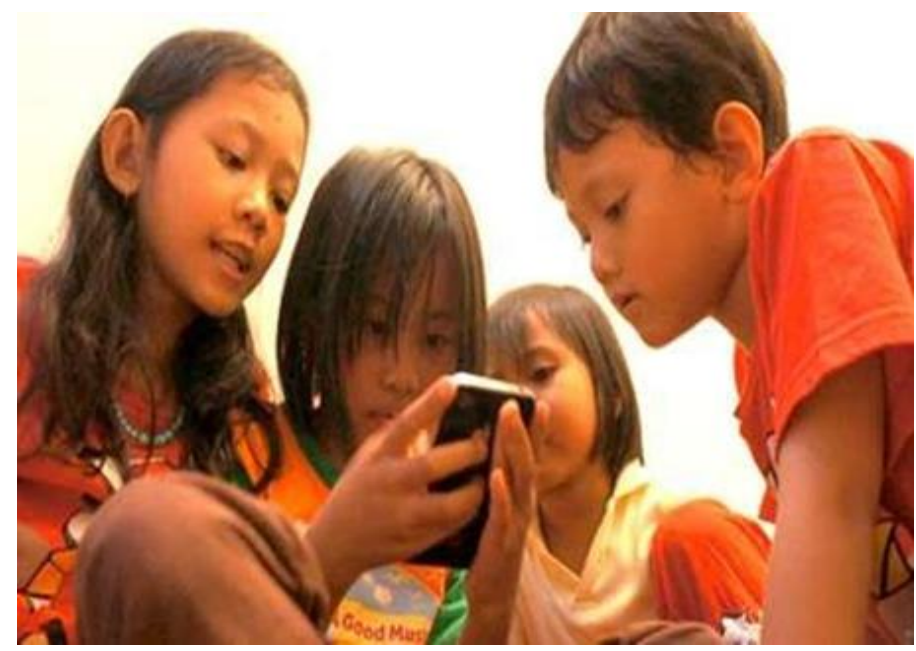

Gambar 2. Anak bermain games di gadget/hp 
Permasalahan Mitra yang ada di kelompok Anak-anak usia 7-12 tahun Desa Tohudan

Colomadu antara lain :

1. Pemanfaatan lapangan yang kurang difungsikan bagi anak-anak untuk bermain dan bergerak.

2. Orangtua yang membiarkan anaknya bermain gadget karena takut anaknya rewel kalau tidak dituruti kemauan anaknya.

3. Belum ada upaya bimbingan untuk orangtua bagaimana solusi mengatasi kecenderungan pemakaian gadget/hp kepada anak.

4. Anak-anak sekarang lebih suka berjam-jam didepan hp dari pada bermain dengan teman-temanya.

Kurangnya sosialisasi anak karena mereka cenderung dirumah tidak kenal dengan tetangga.

\section{Metode}

Metode pelaksanaan kegiatan PKM dengan cara penyuluhan (penjelasan teoritis) dengan porsi $20 \%$ dan kegiatan praktek dengan porsi $80 \%$. Tahap-tahap kegiatan meliputi sosialisasi, dilanjut praktek, monitoring dan pendampingan.

1. Observasi Awal

Pada tahap ini tim PKM melakukan observasi atau survey untuk mengetahui kondisi dan permasalahan yang dihadapi dilokasi pengabdian yaitu Desa Tohudan, Kecamatan Colomadu, Kabupaten Karanganyar selanjutnya mencari solusi untuk mengatasi permasalahan. Tim menggali permasalahan melalui diskusi bersama kelompok anak-anak usia 7-12 tahun.

\section{Persiapan Pelaksanaan}

Tim melakukan persiapan pelaksanaan kegiatan berupa pengurusan ijin ke Kelurahan Desa, Tohudan Kecamatan Colomadu. Selanjutnya mengadakan sosialisasi dalam forum pertemuan kelompok orangtua desa Tohudan untuk memberikan penjelasan kegiatan yang akan dilakukan, tahap-tahap kegiatan serta merencanakan waktu pelaksanaan.

Pada tahap ini Tim PKM juga mulai menyiapkan segala sesuatu untuk membuat berbagai alat dari model permainan untuk pelaksanaan kegiatan.

3. Pelaksanaan kegiatan

Kegiatan diawali dengan penyuluhan yang bertujuan untuk memberikan penjelasan secara teoritis mengenai kegiatan, diawali dengan penyuluhan yang bertujuan untuk memberikan penjelasan secara teoritis mengenai materi yang akan dipraktekkan. Pada kesempatan ini diberikan penjelasan mengenai bagaimana solusi mengatasi kecenderungan pemakaian gadget/hp kepada anak. Pihak orang tua yang ada di Desa Tohudan Colomadu juga akan diundang pada kegiatan ini karena berpartisipasi dalam pelaksanaan kegiatan yang dilakukan. Para orangtua dimotivasi untuk mengikuti pelatihan karena melihat perkembangan anak melalui aktivitas fisk dan gerak semakin berkurang. Anak-anak juga dimotivasi meningkatkan semangat melakukan kegiatan tersebut karena perkembangan motorik dan kognitif mereka menjadi meningkat tidak mudah lelah dan terhindar dari berbagai penyakit. Kegiatan praktek 
berupa penerapan inovasi model-model permainan melalui aktivitas fisik dan gerak anak. Bagi kelompok orangtua untuk dapat membuat inovasi model permainan dan menerapkannya kepada anak-anak sebagai lahan penghasilan tambahan untuk dapat mempromosikan aktivitas fisik dan gerak melalui yang dikemas menarik seperti outbound tersebut baik di desa Tohudan sendiri maupun didesa-desa yang lain.

4. Monitoring

Setelah kegiatan pelatihan terlaksana, selanjutnya kegiatan ini dipraktekan kepada anak-anak desa Tohudan usia 7-12 tahun. Tim PKM melakukan monitoring untuk memastikan bahwa peserta sudah mempraktekan model- model permainan yang dibuat selama jadwal yang sudah ditentukan dan mencari solusi apabila terjadi hambatan atau permasalahan. Tim sanggup memberikan pendampingan meskipun kegiatan PKM telah selesai agar pembelajaran lebih efektif dan berkualitas bisa berlanjut dan berkembang sehingga perkembangan fisik anak menjadi meningkat.

5. Partisipasi mitra

Mitra dalam kegiatan PKM ini yaitu kelompok anak-anak di Desa Tohudan. Berdasar kesepakatan antara Tim PKM dengan kelompok anak-anak di Desa Tohudan, kelompok anak-anak di Desa Tohudan tersebut yang dipilih sebagai mitra strategis yang nantinya akan menyebarluaskan pengetahuan dan keterampilan yang didapat kepada kelompok lainnya dan warga yang membutuhkan. Mitra bersedia mengikuti kegiatan PKM hingga selesai yang dibuktikan dengan surat pernyataan dan sanggup mnyediakan tempat dan pelaksanaan praktek inovasi model permainan.

6. Evaluasi

Evaluasi dilakukan untuk mengukur tingkat keberhasilan kegiatan yang telah dilakukan dengan indikator tertentu sebagaimana diuraikan pada tabel 3 .

Tabel 1. Indikator Keberhasilan Program PKM

\begin{tabular}{llll}
\hline No & \multicolumn{1}{c}{ Masalah } & \multicolumn{1}{c}{ Solusi yang } & \multicolumn{1}{c}{ Indikator keberhasilan/ Target } \\
\hline 1 & $\begin{array}{l}\text { Pemanfaatan } \\
\text { lapangan yang } \\
\text { kurang difungsikan } \\
\text { bagi anak-anak untuk } \\
\text { bermain dan } \\
\text { bergerak. }\end{array}$ & $\begin{array}{l}\text { Memberikan penyuluhan } \\
\text { dengan memanfaatkan } \\
\text { lapangan bagi anak- anak }\end{array}$ & $\begin{array}{l}\text { 90 \% kelompok orang tua dan } \\
\text { anak- } \\
\text { anak di Desa Tohudan bisa } \\
\text { mendapatkan manfaat dari } \\
\text { implementasi inovasi model-model } \\
\text { permainan }\end{array}$ \\
& & \\
$\begin{array}{l}\text { Belum ada upaya } \\
\text { bimbingan untuk } \\
\text { orangtua bagaimana } \\
\text { solusi mengatasi } \\
\text { kecenderungan } \\
\text { pemakaian } \\
\text { gadget/hp kepada } \\
\text { anak. }\end{array}$ & $\begin{array}{l}\text { Dengan membuat anak- } \\
\text { anak lebih aktif dapat } \\
\text { bersosialisasi mudah }\end{array}$ & $\begin{array}{l}\text { Mampu meningkatkan } \\
\text { berkembangan fisik anak melalui } \\
\text { fisiknya tidak terhambat }\end{array}$ & \\
\hline
\end{tabular}




\section{Hasil dan Pembahasan}

Kegiatan pengabdian masyarakat ini yaitu 20 anak khusus usia 7-12 tahun dan orang tua. Kegiatan yang pertama melakukan pelatihan parenting kepada orangtua anak tentang bagaimana mengatasi kecenderungan dagget/hp kemudian dipraktekan inovasi model-model permainan kepada anak. Berikut contoh macammacam model permainan melalui aktivitas fisik dan gerak yang akan diaplikasikan yaitu :

1. Mengambil Bola Secara kelompok

Tujuan dari permainan ini yaitu meningkatkan motorik anak, meningkatkan kerjasama setiap individu, dan meningkatkan keberanian. Cara melakukanya itu dengan saling berkaitan antar anak kemudian mengambil bola yang berada didepan dengan jarak tertentu dengan mengikuti intruksi dari pemandunya. Peserta terdiri dari 4 atau 6 anak. permainan tersebut maka diharapkan kegiatan tersebut dapat terus berjalan serta untuk dapat membuat inovasi model permainan dan menerapkannya kepada anak-anak digunakan sebagai lahan penghasilan untuk dapat mempromosikan aktivitas fisik dan gerak melalui outbound tersebut baik di desa Tohudan sendiri maupun didesa-desa yang lain.

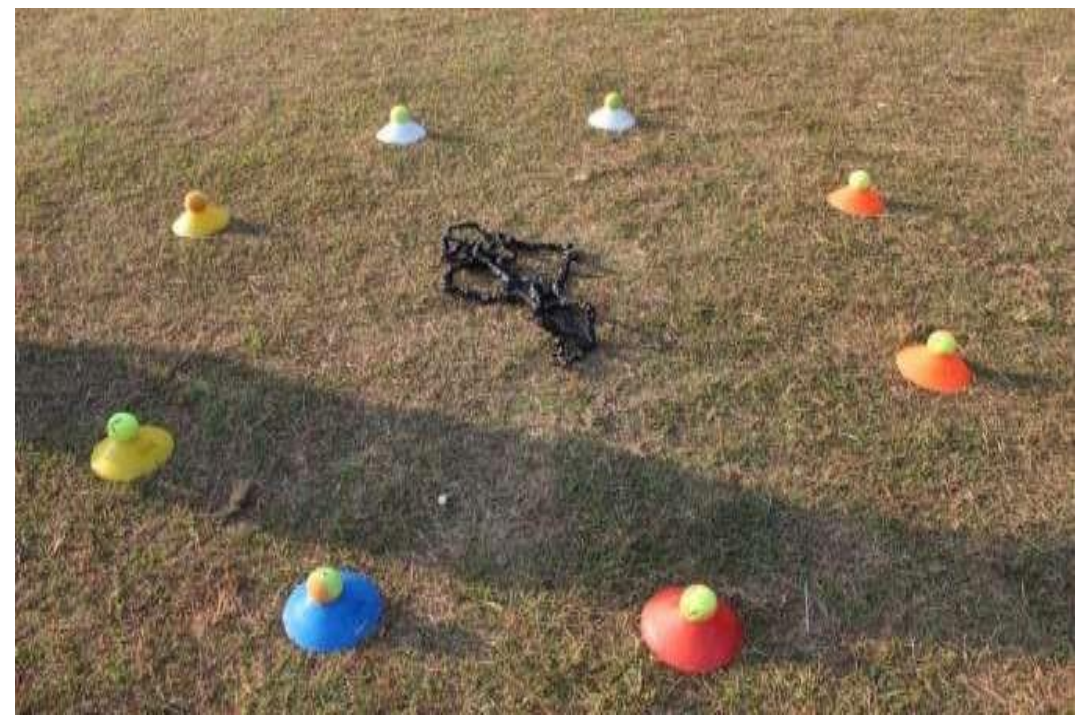

Gambar 5. Permainan bola secara kelompok

\section{Permainan ular tangga}

Tujuan permainan ini adalah melatih kekuataan pada anak, dan melatih kerjasama. Cara melakukannya setiap team terdiri dari 5 anak kemudian melempar dadu dan disetiap nomor ada perintah suruh mengerjakan apa yang ada dalam perintah tersebut.

Perintah disetiap nomor ular tangga di antaranya adalah engklek, lompat ke samping, pakai hola hop, joget, menari, menyanyi, dan lompat kedepan. Alat yang digunakan antara lain lapangan ular tangga, dadu, kun/segitiga (warna :merah, biru, kuning), dan musik 


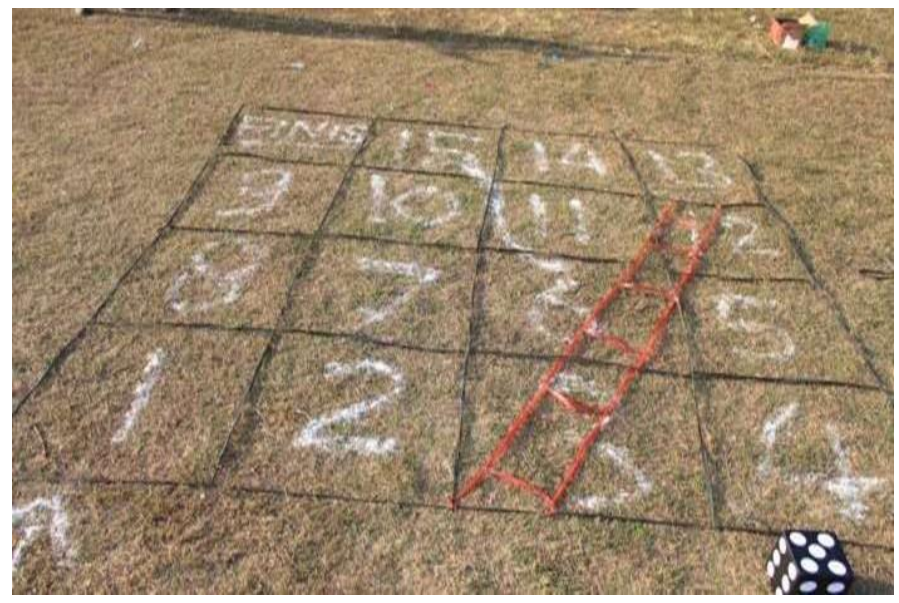

Gambar 6. Permainan Ulartangga

3. Melewati jaring dengan mencocokkan pazzle

Tujuan dari permainan ini melatih kecepatan, melatih kekompakan/kerjasama. Cara melakukan nya yaitu melewati jaring dengan membawa pazzel kemudian dipasangkan setelah itu kembali melewati jarring dan bergantian dengan temannya satu team sampai tersusun pazzelnya dan team itu yang menang. Alat yang digunakan adalah tali raffia, tongkat, peluit, dan pazzle

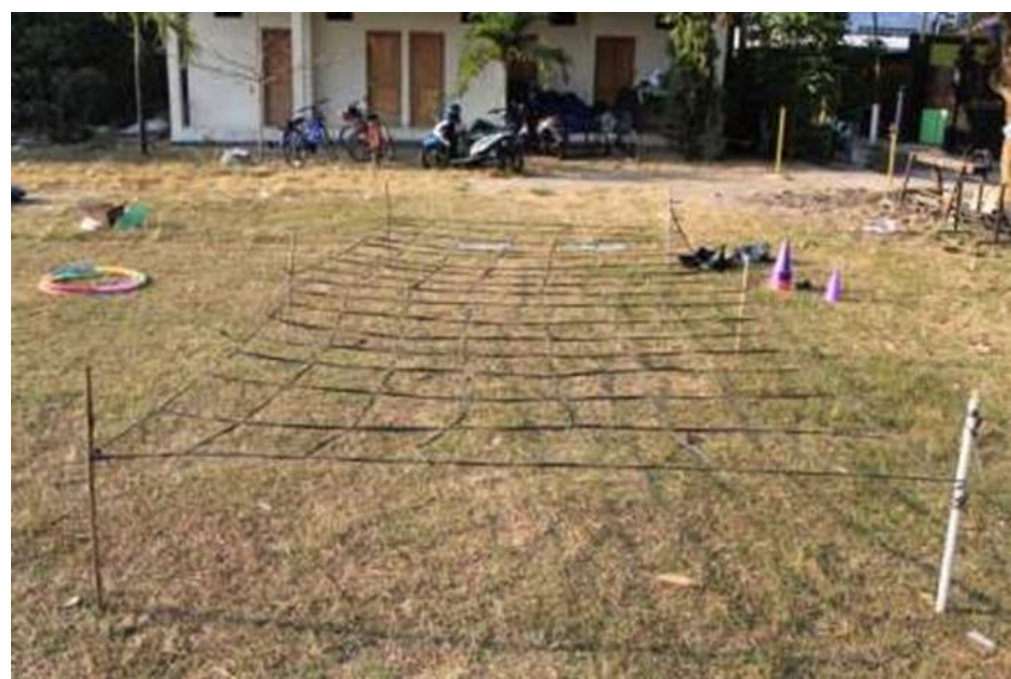

Gambar 7. Permainan jaring mengunakan pazzel

Dari penerepan model-model permainan untuk anak usia 7-12 tahun desa Tohudan di atas didapatkan hasil yang diharapkan terbukti dari :

1. Antusiasme anak dalam mengikuti aktivitas fisik dan gerak setiap pos permainan yang diperintakan sangat tinggi.

2. Anak menjadi lebih aktif senang gembira dengan inovasi model-model permainan yang dilakukan.

3. Meningkatnya pengetahuan kepada orangtua tentang pentingnya perkembangan fisik pada anak. 
4. Dapat mengatasi kecenderungan pemakaian gadget/hp kepada anak dengan cara mengalihkan penggunaan gadget/hp dengan kegiatan fisik yang menyenangkan.

Berikut ini adalah gambar pelaksanaan kegiatan pengabdian masyarakat yang berjudul implementasi model-model permainan melalui aktivitas fisik dan gerak untuk anak usia 7-12 tahun desa Tohudan :

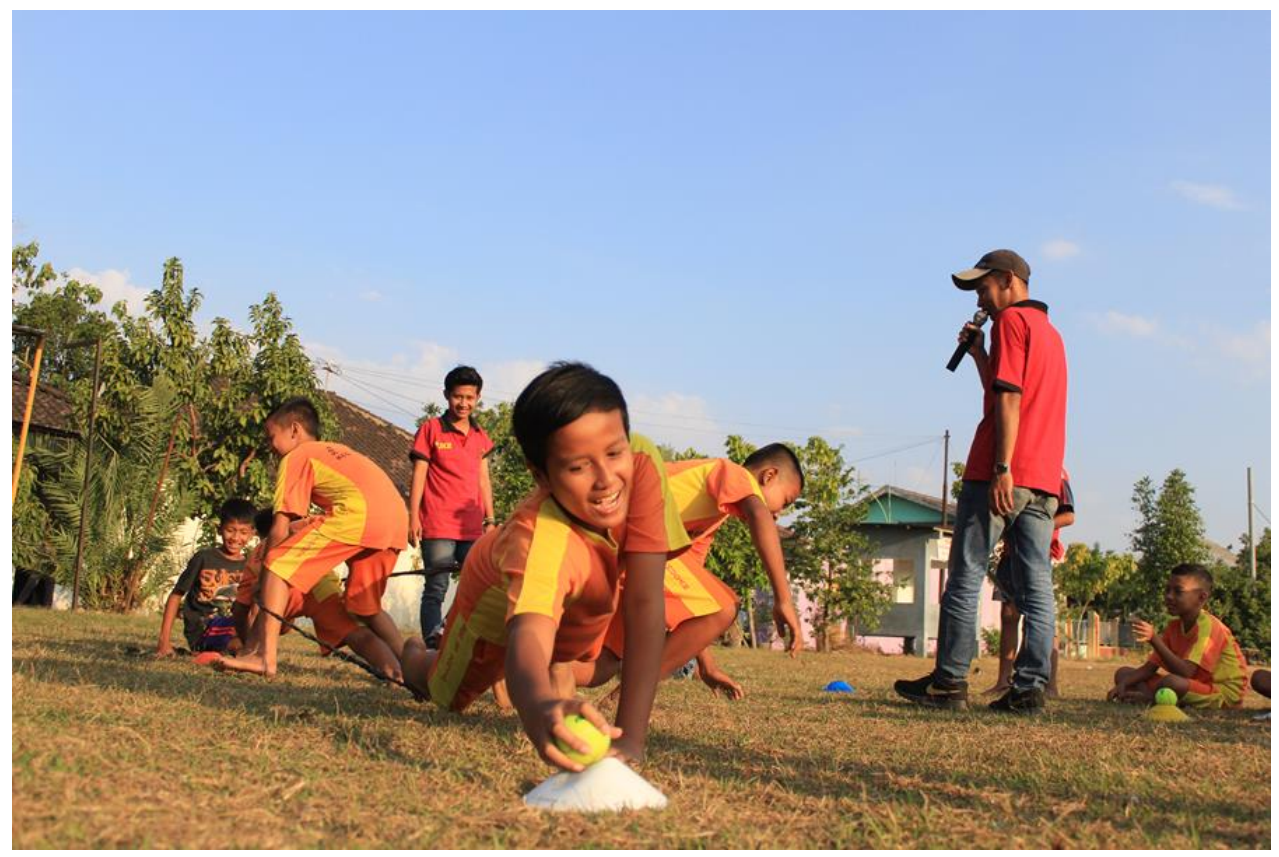

Gambar 8. Permainan bola secara kelompok

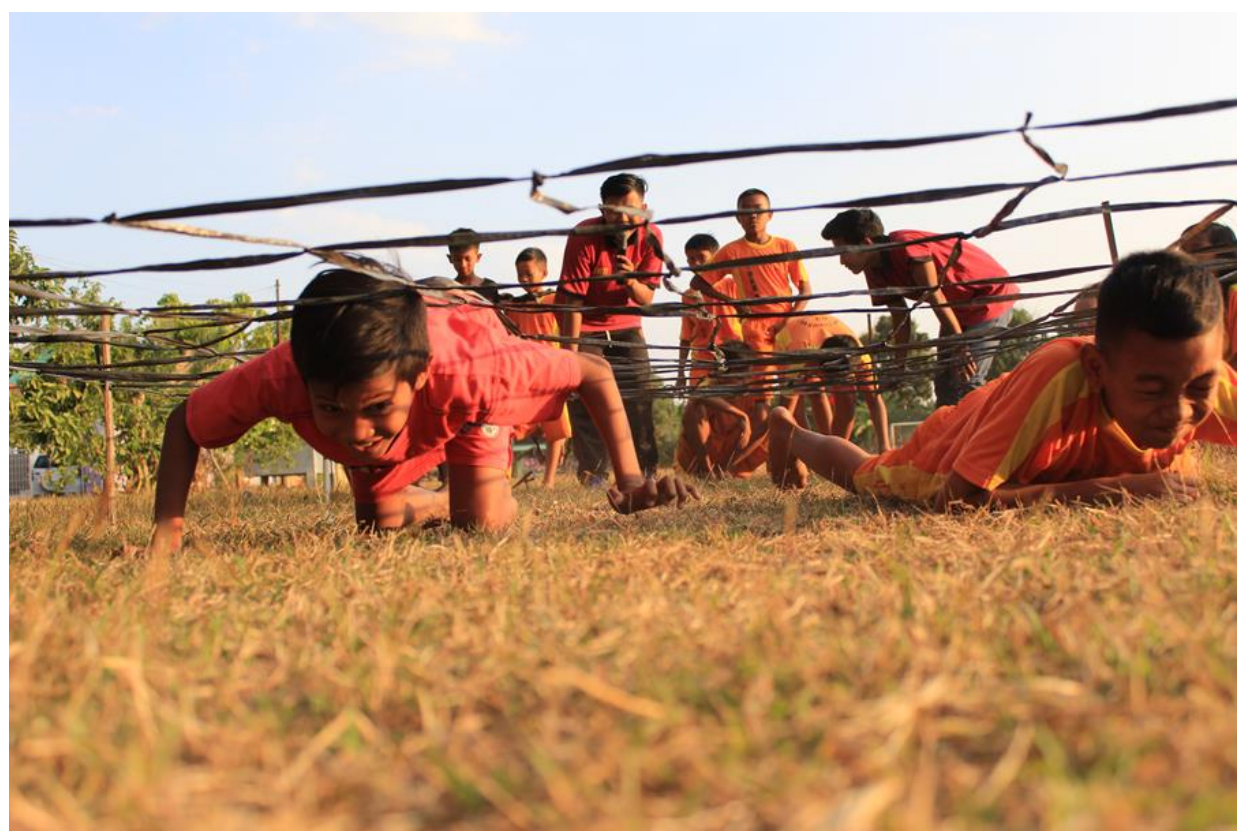

Gambar 9. Permainan jarring mengunakan pazzel 


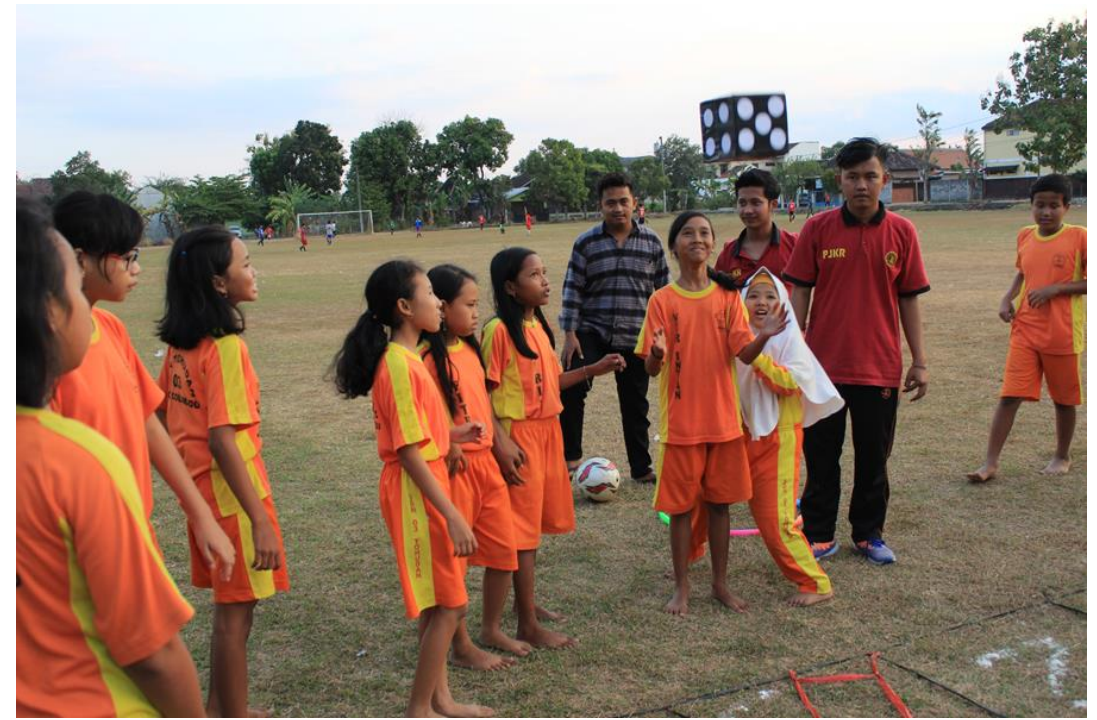

Gambar 10. Permainan Ulartangga

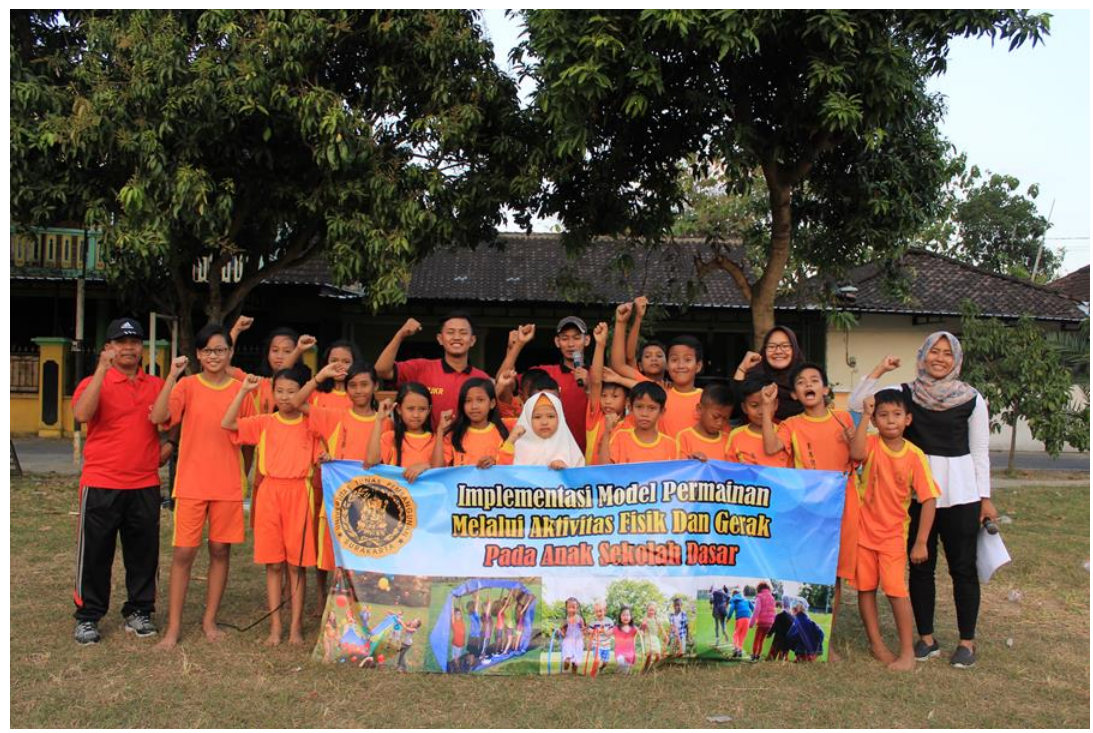

Gambar 11. Foto Bersama Kegiatan Implementasi Model Permainan

\section{Kesimpulan}

Dari pengabdian kepada masyarakat ini dapat disimpulkan bahwa :

1. Pentingnya aktivitas fisik dan gerak anak untuk perkembangan karakter anak baik dari perkembangan motorik dan kognitif melalui inovasi model-model permainan.

2. Diharapkan kegiatan ini dapat berjalan terus dengan membuat inovasi model permainan yang lain sehingga menjadikan anak semakin semangat mengikuti kegiatan.

3. Dapat digunakan sebagai lahan penghasilan untuk mempromosikan aktivitas fisik dan gerak melalui kegiatan outbound tersebut baik di desa Tohudan sendiri maupun didesa-desa yang lain. 


\section{Daftar Pustaka}

Linder, M.C. (1992). Biokimia Nutrisi dan Metabolisme. Universitas Indonesia. Jakarta.

Mahendra, Agus. (2007). Teori Belajar Motorik. Bandung: FPOK Universitas Pendidikan Indonesia.

Mulyasa. (2008). Sertifikasi Guru dalam Proses Pembelajaran. Bandung: Alfabeta.

M. Yudha Saputra, (2007). Pembelajaran Atletik di Sekolah Dasar, Jakarta: Kencana.

Yudanto. (2011). Implementasi Pendekatan Taktik Dalam Pembelajaran Invasion Games di Sekolah Dasar. Fakultas Ilmu Keolahragaan Universitas Negeri Yogyakarta 